\title{
A construção de um itinerário metodológico: o trançar das fontes orais, visuais e escritas em investigações sobre o Mobral
}

\author{
Jailson Costa da Silva* \\ ORCID iD 0000-0001-5078-3603 \\ Instituto Federal de Educação, Ciência e Tecnologia de Alagoas, Campus Piranhas, Alagoas, Brasil
}

\begin{abstract}
Resumo: $\mathrm{O}$ artigo tem como objetivo apresentar os fios trançados na construção do itinerário metodológico de pesquisas ancoradas em fontes orais, fotográficas e acervos documentais. Como resultados das imersóes nos sertóes alagoanos, tais fontes se constituíram enquanto memórias carregadas de narrativas sobre o Mobral (1970-1985). O texto traz as experiências vivenciadas pelo pesquisador que neste espaço enquanto narrador - enuncia a construção de um itinerário iniciado em 2011. A História oral foi a trilha inicial, auxiliada por outras fontes que demonstram a necessidade de recriação das açóes do Mobral, no contexto da Ditadura civil-militar. As fontes evidenciam como os sertanejos reconstruíram sentidos em suas culturas, fazendo-se sujeitos a partir das experiências vividas. Desconstruíram ideias prontas e acabadas; revelaram a complexidade da escuta. Essa imersão permitiu o soar de novas interpretaçóes que afloram de memórias e de histórias de vida marcadas pela experiência.
\end{abstract}

Palavras-chave: Educação de Jovens e Adultos. Fontes históricas. Narrativas. Sertôes.

Developing a methodological itinerary: the result of oral, visual and written investigations about Mobral

Abstract: This paper aims to present the results of the methodological itinerary of research carried out with oral, photographic and documentary sources. As result from the immersions in the sertão of Alagoas, the sources were memories filled up with narratives about the Mobral (1970-1985). The text brings the experiences of the researcher who - as a narrator - tells the construction of an itinerary that started out in

Doutor em Educação pela Universidade Federal de Alagoas (Ufal), com período sanduíche no Programa de Pós-Graduação em Educação da Universidade do Estado do Rio de Janeiro (ProPEd/UERJ). Professor do curso de licenciatura em Física do Instituto Federal de Alagoas (Ifal), área: Formação de Professores. E-mail: jailson.costa@ifal.edu.br. 
2011. The research began with the Oral history method, aided by other sources, demonstrating the need to recreate the actions of the Mobral, in the context of the civil-military dictatorship. These sources show us how the sertanejo rebuilt meanings in their cultures, making themselves lived experience subjects. They deconstructed finished ideas and revealed the complexity of listening. This immersion allowed a glimpse of new interpretations that emerge from memories and life stories marked by experience.

Keywords: Youth and adult education. Historical sources. Narratives. Sertóes.

\title{
Introduzindo o percurso
}

\author{
A igreja de Santana do Ipanema "pegou fogo"! \\ A prefeitura de Santana do Ipanema, "Meteram fogo"! \\ Não é que "Botaram Fogo na Coletoria de Santana do Ipanema"! \\ "Virou arcanfô o registro de documentos de Santana"! \\ "Quem precisar de batistério, tem que pedir a Antônia de Zé \\ Maximiano, que ela vai na Igreja e testemunh a as datas de \\ nascimento e batismo, e o padre dá a certidão"!
} (Barros, 2010, p. 65)

Este trabalho partiu de reflexóes e (re) direcionamentos empreendidos nos âmbitos do Mestrado e Doutorado, em contextos nos quais estudei a questáo da memória via estudos da História oral como ferramenta metodológica para investigar acerca do Movimento Brasileiro de Alfabetização (Mobral). Buscou-se enovelar tais problematizaçôes com contribuiçóes sobre a educação popular e a educação de jovens e adultos no Brasil.

Desse modo, a partir de um retorno aos passos situados em um campo no qual investigo desde 2011, vale destacar que o texto em questáo estrutura-se em quatro tópicos. No primeiro, apresento parcialmente minha trajetória acadêmica e os temas que perpassam as discussōes a serem efetuadas posteriormente. No segundo, privilegio a História oral enquanto metodologia, destacando a importância da memória para a reconstruçáo histórica do Mobral. O terceiro tópico é reservado à apresentaçăo da história grafada nas fotografias, com destaque nas narrativas que as imagens carregam, compreendendo-as como fontes. Por fim, apresento, no quarto tópico - o contato com fontes escritas - a análise de documentos encontrados em acervos até então inexplorados. 


\section{Primeiro itinerário: percursos e trançados em torno de um tema que não cessa de se reinscrever}

Em busca da construção de novos saberes refaço, neste texto, o itinerário metodológico percorrido no âmbito das minhas pesquisas, caminho iniciado no Mestrado, ${ }^{1}$ em 2011, e retomado no Doutoramento, no período de 2014-2018. Nesse sentido, o artigo tem como objetivo apresentar os fios trançados na construção do itinerário metodológico de pesquisas ancoradas em fontes orais, fotográficas e escritas. As narrativas construídas neste texto são tidas como fortes experiências vivenciadas pelo pesquisador que, nesse espaço de autoria - enquanto narrador -, expressa seus sentimentos, tal como define Larrosa (2011, p. 68): "O que narra é o que leva para frente, apresentando-o de novo, o que viu e do qual conserva um rastro em sua memória. [...] expressa, no sentido de exteriorizar, o rastro que aquilo que viu deixou em sua memória”.

$\mathrm{O}$ inacabamento mostrou-me questóes ainda não problematizadas no meu objeto de pesquisa - O Movimento ${ }^{2}$ Brasileiro de Alfabetização (Mobral) - criado por um governo autoritário no âmbito da educação de adultos, em 1967, “[...] por oposiçáo e como alternativa aos movimentos sociais e educacionais inspirados na pedagogia de Paulo Freire" (Ferraro, 2009, p. 110). O Movimento foi implementado apenas em 1970, com um Programa de Alfabetizaçáo Funcional (PAF), ${ }^{3}$ que perdurou até 1985. Vale destacar que o Mobral tinha "[...] autonomia administrativa e financeira, com definição legal de recursos em volume e tamanho para 'resolver', em dez anos, uma questáo nacional: o analfabetismo de largo contingente da populaçáo". (Paiva, 2009, p. 165). Essa autonomia justifica a extrapolação do campo da alfabetização, com a criação de novos programas e a vigência de sua atuação que, prevista para dez anos, prolongouse por mais cinco.

O contexto histórico foi o da Ditadura civil-militar ${ }^{4}$ que, conectada ao golpe do fatídico ano de 1964, instaurou-se no Brasil por vinte e um anos. Sobre a Ditadura,

1 Este estudo teve como objetivo situar, após quatro décadas, os impactos/contribuições do PAF/Mobral na formação dos sujeitos do sertão alagoano, no período de 1970-1985.

2 O Mobral nasceu como Fundação amparada pela Lei n 5.379, de 15 de dezembro de 1967. Era originalmente financiado por recursos provenientes da Loteria Esportiva e da indicação de até $2 \%$ do Imposto de Renda (IR) devido por pessoas jurídicas.

3 O PAF era um programa que, assumindo desde a nomeação - funcional - a concepção de um modo de alfabetização, tinha a finalidade de utilizá-la para aplicação imediata no cotidiano, o que deveria ser feito em prazos curtos, revertendo rapidamente a condição da mão de obra trabalhadora até então analfabeta, agora requerida como, minimamente, alfabetizada.

4 Utilizo o termo Ditadura civil-militar, entendendo que o golpe de 1964 foi fruto de uma coalizão civil e militar. Confirmou-se com a ascensão de um novo bloco no poder que envolvia a articulação entre o conjunto das classes dominantes, a exemplo, a burguesia industrial e financeira nacional e internacional, “[...] bem como uma camada (de caráter civil) de intelectuais e tecnocratas" (Germano, 2011, p. 17). 
pode ser assinalado que esta operou como um regime de exceção, elaborando políticas públicas de violação de direitos humanos, a saber: a repressáo política violenta; o aumento das desigualdades sociais com o alargamento da concentraçáo de renda; a rígida política de arrocho salarial; a legalização da concentração fundiária, que permitiu a apropriação indevida das terras e a expulsão dos trabalhadores rurais.

Nesse contexto, na esfera da educação de adultos, o Mobral criou vários programas, como estratégia de sobrevivência institucional do órgáo, que encontrava legitimidade e autonomia na vigência dos governos autoritários: "Um grande sistema de educação permanente a serviço da segurança interna do regime e do sistema de dominação era a grande tarefa do Mobral" (Paiva, 2003, p. 382).

Tranço aqui narrativas provenientes dos sertốes 5 alagoanos, região que demonstra pouco apreço à preservaçáo da memória escrita, sobretudo quando esses documentos são grafados por interesses políticos. Na epígrafe que abre estes escritos, a antropóloga santanense Luitgarde Barros, chama a atenção para esse descaso com a memória, destacando sua dificuldade em escrever sobre Santana do Ipanema (AL); 6 tal dificuldade ocorre porque "as chuvas terminaram carregando para o Ipanema [rio que corta a cidade] as cinzas dos dados documentais [...]" (Barros, 2010, p. 65)

O desejo em dar continuidade à investigaçáo, iniciada no Mestrado, surgiu da constataçáo de que, no âmbito do Mobral, nos sertóes alagoanos, muitas reflexôes ainda permaneciam em aberto. Retomei os meus passos tendo como base não apenas as respostas alcançadas pela dissertação defendida, mas, principalmente, a partir das novas inquietaçóes que floresceram pelos achados da investigação que, por motivos óbvios, não puderam ser aprofundadas no curto período reservado ao Mestrado.

$\mathrm{Na}$ pesquisa de Doutorado, ${ }^{7}$ optei por estudar as açóes culturais desenvolvidas pelo Mobral. Para isso, a abordagem qualitativa da História oral constituiu o trançado metodológico, por desempenhar o papel de reconhecimento dos sujeitos guardiōes da memória (Alberti, 2008; Portelli, 1997, 2010; Thompson, 1992). A memória ganhou, a partir do testemunho oral, uma característica de fonte histórica, bem como de objeto de análise (Amado, 1995; Pollak, 1989, 1992).

O enlear dos fios que foram construindo os itinerários das pesquisas, levaram-me

5 Uso sertões, no plural, por reconhecer a diversidade que povoa esses espaços, o que nos impede de conceber o sertão no singular. Neste "[...] recorte espacial [registramos a nossa] identidade regional [que] guarda em seu interior a diferença, a diversidade, a multiplicidade de realidades e [...] de representações" (Albuquerque Jr., 2014, p. 42).

6 Conta com uma população de 48.232 habitantes, com área territorial de 437,90 $\mathrm{Km}^{2}$ e densidade demográfica de $110,14 \mathrm{hab} / \mathrm{km}^{2}$. O Índice de Desenvolvimento Humano Municipal (IDHM) era 0,591, em 2010, o que situa esse município na faixa de desenvolvimento humano baixo (Atlas do Desenvolvimento Humano no Brasil, 2017).

7 A pesquisa teve como objetivo compreender, a partir da tessitura das histórias e memórias, como os sertanejos experienciaram e ressignificaram as ações culturais desenvolvidas pelo Mobral no contexto de Ditadura civil-militar. 
à história grafada nas fotografias, destacando as narrativas que as imagens carregam em si, e muitas outras que podem ser imaginadas e interpretadas a partir delas (Leite, 1993; Mauad, 1996, 2010), memórias do acervo pessoal dos entrevistados, cedidas durante as entrevistas.

Em minhas incursóes nas pesquisas, entrei em contato com fontes escritas, por meio da memória material de acervos documentais recuperados pelo Centro de Referência e Memória da Educação Popular e Educação de Jovens e Adultos (Cremeja) e da Educaçáo de Jovens e Adultos (EJA) da Universidade do Estado do Rio de Janeiro (UERJ). Esse acontecimento tornou possível o aprofundamento dos meus estudos sobre o Mobral. Nesse contexto, tive a oportunidade não só de explorar o acervo recuperado, mas de acompanhar o trabalho de catalogaçáo documental relativo à EJA, enfatizando a organização do acervo que estava sendo criado no meu período ${ }^{8}$ de estadia na UERJ. Outro arquivo explorado que passou a enriquecer as pesquisas foi o acervo que professor Osmar Fávero organizou ao longo de seis décadas: o arquivo foi organizado pelo Núcleo de Estudos e Documentação em Educação de Jovens e Adultos (Nedeja) da Universidade Federal Fluminense (UFF) e reúne mais de mil fontes documentais do campo da Educação Popular e da EJA no Brasil.

As pesquisas realizadas durante o Mestrado e o Doutorado passaram a fazer parte de um contexto mais amplo, que diz respeito à organização do Cremeja ${ }^{9}$ e da EJA, articulando-se a uma rede de interlocuçáo de pesquisadores da Universidade Federal de Alagoas (Ufal) e da UERJ, por meio do Programa Nacional de Cooperaçáo Acadêmica e do Conselho Nacional de Desenvolvimento Científico e Tecnológico (Procad/CNPq).

Consciente da ausência da memória escrita sobre as açôes do Mobral nos sertóes alagoanos, retomei as investigaçóes sobre o Programa Mobral Cultural, seguindo as trilhas da História oral. As pistas deixadas pela pesquisa anterior levaram-me a outros interlocutores que contaram suas experiências, compartilharam suas lembranças e ajudaram a preservar parte da história do Movimento. Benjamin (2012, p. 221), preocupado com a extinçáo da arte de contar histórias, alertou-me ao dizer: "ela se perde porque ninguém mais fia ou tece enquanto ouve a história.” Ouvir com atenção e aprender com a experiência narrada, e esse foi um exercício que procurei fazer durante as entrevistas, na busca de tecer e fiar novas interpretaçóes acerca das açóes do Mobral em terras sertanejas. Desse modo, olhar para a história, a partir dos sujeitos ordinários e esquecidos, segundo Certeau (2011) e Benjamim (2012), respectivamente, tornou-se

8 Período sanduíche no Programa de Pós-Graduação em Educação (ProPEd), da UERJ.

9 Os Centros de Referência e Memória constituíram-se como política pública da Secretaria de Educação Continuada, Alfabetização e Diversidade (SECAD/MEC), nos anos 2008 - 2010, acolhidos como tais, a partir de projeto submetido àquela Secretaria por pesquisadores de diversas universidades públicas. Durante a vigência da SECAD, muitas ações foram desenvolvidas e financiadas em núcleos de universidades desejosos de reconstruírem a memória dispersa de ações populares e de EJA em todo o país. 
um posicionamento assumido por mim, na construção destes estudos.

Nessas pesquisas, privilegiei as narrativas memorialísticas de sertanejos, partícipes das açôes do PAF e do Mobral Cultural, bem como os depoimentos de outros sujeitos que participaram diretamente das açóes desenvolvidas pelo Mobral no município de Santana do Ipanema e em outros municípios dos sertóes alagoanos que, de forma surpreendente, aprovaram as açóes de um Movimento criado pela Ditadura civilmilitar. A relevância dessas pesquisas justifica-se pela necessidade de preencher, mesmo que minimamente, a lacuna da história da educação em Alagoas, especificamente no âmbito da Educação de Jovens e Adultos (EJA), agregando-se aos estudos já existentes de Freitas e Moura (2007). Recuperar a memória constitui, assim, o primeiro passo para reconstruir a história que, no caso da educação popular e da EJA, nem sempre fizeram parte dos registros da história da educação brasileira.

\section{Segundo itinerário: a História oral como metodologia}

A reconstrução da história de um Movimento, como o Mobral, que teve sua origem há mais de cinco décadas e, especialmente, em uma região onde as pessoas não têm a cultura de conservar documentos escritos, sobretudo na área de educação e, especificamente, no campo da EJA, foi uma tarefa difícil. Nos sertóes alagoanos, essa escassez de fontes escritas sobre a história do Mobral acentuou-se. Isso foi traduzido na narrativa da Sra. Jeniuza Soares de Melo (2012), ex-supervisora de área ${ }^{10}$ de Santana do Ipanema: "Olhe! Aqui em Santana, todo material foi mandado para um depósito, não só do Mobral como dos funcionários antigos, um depósito [...] até depois disseram que queimaram, mas eu acho que é estória!”. Essa narrativa ilustra a minha dificuldade de localizar na Secretaria de Educação Municipal de Santana do Ipanema registros acerca da origem do Movimento desde as pesquisas feitas no Mestrado, em 20112012. Foi esse o fato que me conduziu à realização de entrevistas, indo em busca de pessoas que experienciaram diretamente os efeitos do Mobral: uma ex-supervisora, exalfabetizadores, uma ex-voluntária e cinco ex-alunos, que participaram do PAF.

As trilhas seguidas no Doutorado conduziram-me para além dos limites geográficos de Santana do Ipanema. Por se tratar de um Movimento presente em todos os municípios, foi recorrente a indicação de pessoas de comunidades vizinhas que participaram das atividades do Mobral. As pistas deixadas pela ex-supervisora de área de Santana do Ipanema levaram-me a um grupo de senhoras que trabalharam na

10 O Sistema de Supervisão estruturava-se em três níveis, havendo um supervisor fixo em cada município, denominado Encarregado da Supervisão Global, um supervisor volante, denominado Supervisor de Área, que tinha como responsabilidade uma média de 5 municípios, e um supervisor que integrava as informações em nível estadual e, por isso, era denominado Supervisor Estadual. 
Coordenaçáo Estadual do Mobral, ao animador das açóes culturais, ao ex-supervisor do município de Páo de Açúcar (AL), bem como aos sertanejos que participaram das açôes do Programa Mobral Cultural. ${ }^{11}$ Considerando as dimensóes reduzidas de um artigo, apresento apenas fragmentos das vozes de três interlocutores.

No percurso das incursóes no campo da pesquisa, a História oral desempenhou um papel fundamental na reconstruçáo de fatos históricos, por meio de entrevistas gravadas com pessoas que puderam testemunhar sobre as açóes do Mobral. Em relação a essa questáo, os escritos de Alberti (2008, p. 155) são enfáticos, ao demonstrarem que "[a] história oral permite o registro de testemunhos e o acesso a "histórias dentro da história’ e, dessa forma, amplia as possibilidades de interpretação do passado". À luz dessa citaçáo, acredito que as pesquisas realizadas contribuíram para evitar, pelo menos em parte, que as memórias dos sertanejos sejam esquecidas, bem como para evitar a relativização das definiçôes generalizantes, comumente atribuídas ao Mobral. Ao destacar as possíveis contradiçóes do fato histórico, a autora alerta que uma das principais qualidades da História oral "está em permitir o estudo das formas como pessoas ou grupos efetuaram e elaboraram experiências, incluindo situaçóes de aprendizado [...]" (Alberti, 2008, p. 165).

Em minhas pesquisas, as memórias foram relembradas pelos depoentes, que transmitiram, por meio do diálogo ocasionado pelas entrevistas, narrativas de um tempo passado, evocadas pela intervenção do pesquisador. Portelli (2010, p. 19-20) destaca a importância da interação entre pesquisador e entrevistado: "a narração oral da história só toma forma em um encontro pessoal causado pela pesquisa de campo. Os conteúdos da memória são evocados e organizados verbalmente no diálogo interativo entre, $[\ldots]$ entrevistado e entrevistador".

Considerando que as lembranças são construçóes do presente sobre o passado, esse encontro que o autor descreve configurou-se como instrumento fundamental na aquisição das informaçóes bem como na problematização das mesmas. O diálogo passou a ser o mediador dessa construçáo, o que colocou o pesquisador na posição de construtor dessas fontes, retirando-o da condição de mero coletor dos relatos.

No decorrer das pesquisas, mantive o foco nas narrativas a partir dos postulados teóricos de Benjamin (2012, p. 220) para quem, diferentemente da informação, que só tem valor enquanto novidade, a narrativa "[...] não se esgota jamais. Ela conserva suas forças e depois de muito tempo ainda é capaz de desdobramentos”. É nesse sentido que privilegiei as narrativas memorialísticas dos sujeitos sertanejos - os narradores que, de forma surpreendente, aprovaram as açôes do Movimento. Essas narrativas,

11 A implantação do Programa Mobral Cultural se deu de forma gradativa em todo o país por meio de duas unidades básicas: o Posto Cultural e a Mobralteca. Sendo uma de caráter fixo - o Posto Cultural - e a outra de caráter itinerante - a Mobralteca. Essas duas unidades operacionais recebiam apoio dos seguintes subprogramas: literatura, publicações, teatro, cinema, música, arte popular e folclore, rádio, patrimônio histórico e cultural, reservas naturais, artes plásticas e televisão. 
impregnadas pela experiência, segundo Alberti, (2008, p. 165), ajudam a "[...] entender como pessoas e grupos experimentaram o passado [o que] torna possível questionar interpretações generalizantes de determinados acontecimentos e conjunturas".

Nessa perspectiva, os relatos do ex-supervisor de área do município de Páo de Açúcar caminharam na perspectiva do entendimento das açóes do Mobral como positivas para os sertanejos, porque conseguiram chegar até as pessoas:

O Mobral, apesar de ter sido criado na Ditadura [...], mas você sabe como é a política coronelista! Vamos colocar nestes termos, a política dos coronéis do sertão é não ensinar a ninguém, absolutamente nada, para que essas pessoas permaneçam na subserviência, o Mobral vinha para justamente abrir a cabeça dessas pessoas. (Hélio Silva Fialho, 2015).

O depoimento permite uma análise das contradiçôes do contexto da Ditadura civil-militar, do sertão alagoano e da presença do coronelismo. Para o narrador, o Mobral, criado com a perspectiva de dominação, abria uma possibilidade de alfabetizaçáo.

Os trabalhos realizados com o uso de entrevistas deixaram-me uma grande liçăo. Ajudaram-me a entender que se dá numa relação de duplo conhecimento, proporcionado pelo diálogo que, a princípio, é tido como formal, mas, em poucos minutos, torna-se agradável e descontraído, com o fluir da conversa, quando "[o]s sujeitos [...] compartilham [em] um espaço narrativo e [em] um espaço físico - e é isso que a torna possível" (Portelli, 2010, p. 55). O tipo de entrevista com que operei nestes estudos é denominada de entrevista temática. Esse tipo de entrevista dedica-se a tratar "[...] prioritariamente sobre a participação do entrevistado no tema escolhido" (Alberti, 2008, p. 175). Visei em todas as entrevistas interagir com os interlocutores, na intençáo de permitir que contassem o que sabiam de maneira espontânea. Para isso, realizei as entrevistas nos locais escolhidos pelos depoentes, que duraram em média de 60 minutos a 3 horas.

Todas as entrevistas foram gravadas, na intenção de não perder a originalidade das falas, seguindo orientaçóes de Thompson (1992, p. 146), que ensina que a gravaçáo apresenta uma grande vantagem sobre os demais registros, pois, nela " $[\mathrm{t}]$ odas as palavras empregadas estáo ali exatamente como foram faladas; e a elas se somam pistas sociais, as nuances da incerteza, do humor ou do fingimento, bem como a textura do dialeto". Na passagem da entrevista para a forma escrita, preocupei-me com fidelidade da transcrição, mesmo ciente da impossibilidade de transcrever fidedignamente as narrativas orais, uma vez que "[a] fileira de tom e volume e ritmo do discurso popular carregam implícitos significados e conotaçóes sociais irreproduzíveis na escrita [...]" (Portelli, 1997, p. 28).

No que diz respeito à interpretação, pude vivenciar, no decorrer dessas pesquisas, os aspectos que as fontes orais permitem ao pesquisador, sobretudo no momento da entrevista: a aproximação da subjetividade do entrevistado e o encontro face a face, que 
possibilitou a apreciação de detalhes imperceptíveis em outras fontes, por exemplo.

A importância da memória para repensar a história pela ótica das pessoas que, de fato, vivenciaram um acontecimento, no caso, os sujeitos dessas investigaçóes, ganha espaço nestes escritos. Esse posicionamento de luta pela memória, no intuito de reconstruir o passado por meio das vozes silenciadas, advém do pressuposto de que os fatos que náo foram registrados pelos documentos oficiais têm, na História oral, a oportunidade de serem contados por meio dos relatos dos narradores.

Entre as especificidades do campo da memória destaco, mesmo que de forma breve, as conexôes existentes entre história e memória. Amado (1995, p. 131) destaca a necessidade de se estabelecer uma distinção entre história e memória. Essa distinção deve iniciar-se com a diferenciaçáo entre o fato vivido e o fato rememorado, ou seja, deve distinguir o que passou - a história - e o que se recorda desse fato ocorrido - as memórias. "Embora relacionadas entre si [...] possuem naturezas distintas, devendo, assim, ser conceituadas, analisadas e trabalhadas como categorias diferentes, dotadas de especificidade".

Há uma imbricação muito forte entre história e memória, apesar das peculiaridades de cada uma. A apresentaçấo dessas assimetrias alertou-me sobre a reelaboraçáo, ou até mesmo seleção, das lembranças que ganham espaço nas narrativas dos interlocutores durante as entrevistas. Isso me levou a compreender que se trata da rememoraçáo, no momento presente, de uma experiência vivida no passado. Segundo Amado (1995), o processo de rememoraçáo atribui novos significados às experiências vividas no passado, sendo que a memória, "ao trazer o passado até o presente, recria o passado [...]" (Amado, 1995, p. 131).

Outro ponto que merece destaque nesta discussão está relacionado à problemática da restituição do passado por meio da memória. Alertado por Bosi (1994), destaco a impossibilidade de resgate do passado. É que para essa autora não é possível reviver o passado a partir da lembrança; é possível apenas a reconstrução e o repensar desse passado, tendo como base as ideias e imagens do presente. Nesse sentido, a autora ressalta que "[a] lembrança é uma imagem construída pelos materiais que estâo, agora, à nossa disposiçáo, no conjunto de representaçóes que povoam nossa consciência atual" (Bosi, 1994, p. 55).

Continuando esse resumo acerca da memória destaco, ainda, nos estudos de Pollak (1989), a ênfase nas memórias subterrâneas que, de forma subversiva, afloram no silêncio e no esquecimento das culturas minoritárias: "Ao privilegiar a análise dos excluídos, dos marginalizados e das minorias, a história oral ressaltou a importância de memórias subterrâneas que, como parte integrante das culturas minoritárias e dominadas, se opóem à 'memória oficial' [...]" (Pollak, 1989, p. 4), a exemplo do que as pesquisas mostraram sobre o Mobral nos sertóes de Alagoas, evidenciando como os sertanejos reconstruíram sentidos em suas culturas, fazendo-se sujeitos a partir das experiências vividas. 
Pollak (1992) apresenta a memória enquanto identidade social. Ele entende a memória como fenômeno coletivo e social, "[um] fenômeno construído coletivamente e submetido a flutuaçôes, transformaçóes, mudanças constantes" (Pollak, 1992, p. 2). O autor ainda destaca os elementos constitutivos da memória individual e da memória coletiva. Segundo ele, estáo presentes no campo da memória individual os acontecimentos vividos pessoalmente, enquanto que o campo da memória coletiva é ocupado pelos acontecimentos, descritos pelo autor como vividos por tabela. Ele referese aos episódios históricos vividos por determinado grupo ao qual a pessoa náo estava inserida. "São acontecimentos dos quais a pessoa nem sempre participou, mas que, no imaginário, tomaram tamanho relevo que, no fim das contas, é quase impossível que ela consiga saber se participou ou não" (Pollak, 1992, p.2). Essas descriçóes do autor acerca da memória coletiva tiveram aparição constante em minhas investigaçóes. Encontrei pessoas que viveram/vivem essa experiência por tabela, e a deixaram ecoar em suas narrativas, construídas pelo imaginário herdado de seus pais ou avós que participaram das açóes do Movimento.

Isso vai ao encontro do que Amado (1995, p. 132) enfatiza ao dizer que a memória tem como característica proporcionar essa associação das experiências vividas pelos indivíduos ou grupos de indivíduos aos sujeitos que não experimentaram diretamente a experiência. "são as vivências dos outros, das quais nos apropriamos, tornando-as nossas também, por meio de conversas, leituras, filmes, histórias, músicas, pinturas, fotografias. Nossas memórias são formadas de episódios e sensaçôes que vivemos e que outros viveram", os fatos rememorados não são mais fruto de memórias individuais, passando a fazer parte de um constructo coletivo, em que os sujeitos envolvidos ajudam-se mutuamente por meio de suas lembranças.

\section{Terceiro itinerário: a fotografia como fonte}

Neste tópico, faço menção à história grafada nas fotografias, destacando as narrativas que as imagens carregam em si, e as muitas outras que podem ser imaginadas e interpretadas a partir delas, enfatizando o trançado entre as fontes orais e visuais, constituintes de narrativas que, interpretadas pelo pesquisador, compóem novas histórias que destacam os significados do Mobral nos sertôes alagoanos.

Os estudos conseguiram reunir um corpus composto por 87 fotografias, caracterizado por imagens diversas que apresentam comportamentos fotográficos variados, em grande maioria de profissionais desconhecidos na atualidade. Todas as fotografias fazem parte do conjunto de memórias do acervo pessoal dos entrevistados e foram cedidas no momento das entrevistas e disponibilizadas para publicaçáo. Os estudos de Leite (1993, p. 165) mostram que essa categoria de imagens tem grande valor, uma vez que é "[f]eita para recordar atos da vida, em sua continuidade, está 
carregada de conotaçôes tanto mais fortes quanto mais condicionadas pelo mundo exterior".

A captação das minuciosidades por meio das imagens fotografadas permitiu, no percurso, o aguçamento do meu olhar nas análises realizadas do acontecimento histórico, possibilitando novas interpretaçóes acerca de um passado que, em um instante, foi fixado na imagem capturada. Nesse sentido, a imagem, enquanto texto, permite aos leitores novas interpretaçóes do passado registrado pela câmera que captura, a partir do olhar do fotógrafo, a imagem que lhe convém, que lhe chama mais a atenção, como é o caso da fotografia a seguir; rica em narrativas, "pois a narração, em seu aspecto sensível, não é de modo algum o produto exclusivo da voz" (Benjamin, 2012, p. 239).

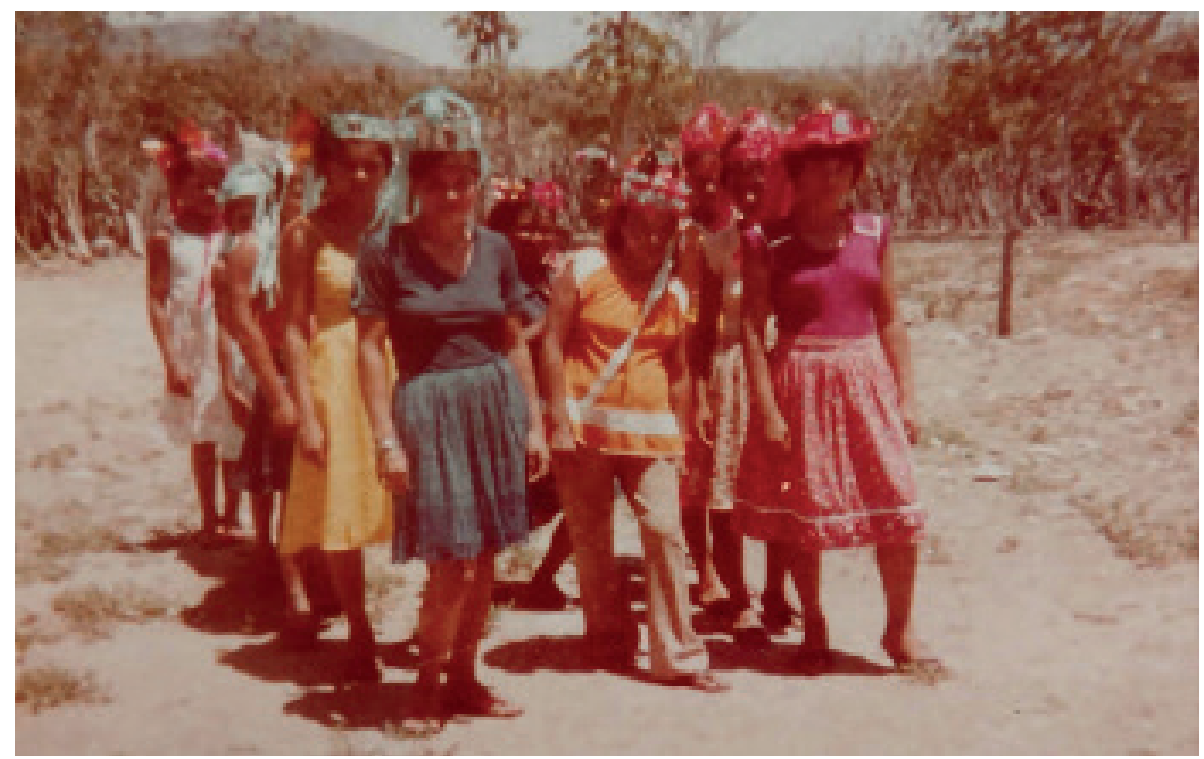

Figura 1- Atividade cultural com as alunas do PAF, 1981.

Fonte: arquivo pessoal de Hélio da Silva Fialho - ex-supervisor de área do Mobral.

A fotografia (figura 1) traz a imagem de um grupo de alfabetizandas do PAF do município de Palestina, também situado nos sertóes alagoanos. Conforme depoimento do Sr. Hélio Silva Fialho, a foto é o registro de uma das apresentaçôes culturais dos alunos do PAF e demonstra como se dava a integração entre o Programa Cultural e o de Alfabetizaçáo. Segundo o narrador, a fotografia capturou o momento em que o grupo se organizava para representar o reisado, ${ }^{12}$ uma das manifestaçóes culturais mais

12 As apresentações dos grupos de reisados nas cidades do sertão estão cada vez mais reduzidas. Duarte (2010, p. 284), ao escrever sobre esse processo de declínio da tradição, explica: "O Reisado alagoano teve sua época de grande fastígio, de esplendor, sendo atualmente substituído pelo folguedo dos guerreiros, sua nova apresentação sincrética. Todavia, ainda é dançado em localidades alagoanas". 
tradicionais de Alagoas.

A fotografia, datada de outubro de 1981, registra o momento de uma das várias apresentaçóes culturais mobilizadas pelo Mobral nos sertóes alagoanos, o que me permitiu realizar a bricolagem (Certeau, 2011), por entender que a fotografia trouxe, em si, narrativas que me ajudaram, junto às fontes orais, a efetuar a leitura dessa imagem. A parada obrigatória para a foto concedeu a análise de um instante em que o grupo, composto por mulheres (característica marcante da EJA), se preparava para se apresentar ao público. Trata-se de mulheres que sofreram interdiçôes no âmbito do exercício do direito à educaçáo em alguma fase de suas vidas, devido a contextos históricos, socioeconômicos e culturais. Ao tratar da invisibilidade das mulheres sertanejas, Moreira (2019, p. 356) nos adverte:

A existência das mulheres nos sertóes aparece vinculada no seio da família, já que esta representa a matriz de reprodução das identidades nesse espaço. Em torno do chefe e de suas alianças familiares, econômicas e políticas, organizaram-se boa parte das tradiçôes do 'sertanejo'. Os códigos da violência e dominação patriarcal estiveram presentes nas dinâmicas domésticas, com uma ideia de família que servia à posse da terra e manutenção das relaçóes de poder [...] As mulheres foram também elas reduzidas a símbolo de posse, exploração e ostentação das práticas de dominação patriarcal [...].

A imagem destaca a criatividade cotidiana das sertanejas, ao improvisarem os trajes típicos do reisado feitos de cetim colorido, bem como os chapéus ilustrados por espelhos redondos, além das flores artificiais e das fitas coloridas. Moreira (2019, p. 358) enfatiza que, na labuta cotidiana, essas mulheres sertanejas criaram mecanismos de sobrevivência, bem como de afirmação diante das estratégias do patriarcado "teceram a vida e a alegria sertaneja que mitigaram a existência árida do sertão patriarcal latifundiário. Foram elas que alimentaram cotidianamente, os corpos e a alma com sentidos, encantos e afetos".

A fotografia demonstra a satisfação das mulheres que encontraram no PAF a oportunidade da alfabetização negada. Como narra a Sra. Alice Silva Farias (2012): "Eu não tinha estudo, porque eu nasci e me criei em uma lei muito rígida [...] Era muito rígida! E eu tinha vontade de aprender ao menos assinar o nome! Aí ele [o pai] dizia: 'pra que moça estudar! [...] pra ficar escrevendo carta, bilhetinho pros namorados' [...]". A entrevistada ainda relatou que quando passou a morar na cidade surgiu a oportunidade de estudar, uma vez que, no ano de 1971, um grupo de pessoas passou nas casas convidando as pessoas que tinham vontade de estudar para se matricularem no Mobral.

O espaço físico representado na imagem nos remete à simplicidade das comunidades rurais do sertáo, num período do ano em que a terra seca contrasta com o verde da vegetação que resistiu até o mês de outubro. $\mathrm{O}$ cenário capturado 
pela fotografia nos faz lembrar da obra de Euclides da Cunha, Os Sertôes, publicada em 1906, com conceitos por ele construídos acerca dos sertôes e dos seus habitantes, imagens muitas vezes ambíguas e contraditórias. $\mathrm{O}$ autor dá ênfase à paisagem que, ao mesmo tempo em que é desoladora e desértica, é também paradisíaca, descrevendo-a como uma terra que vai "[d]a extrema aridez à exuberância extrema" (Cunha, 1981, p. 231). Os estudos de Albuquerque Jr. (2011, p. 66) mostram que a publicação do livro representou o início da procura do verdadeiro Brasil. "Com ele, teríamos iniciado a busca da nossa origem, do nosso passado, da nossa gente, da nossa terra, dos nossos costumes, das nossas tradiçóes. Teríamos ficado conhecendo, com ele, a influência do ambiente sobre o nosso caráter e a nossa raça em formação".

Esse exercício com as imagens segue os ensinamentos de Leite (1993, p. 149), que afirma ser necessária uma sensibilidade para a percepçáo das narrativas contidas nas fotografias, uma vez que "[n]áo se procura na fotografia apenas o que comprove as análises históricas verbalizadas, mas sim informaçôes, dimensôes e relaçôes que as verbalizaçôes não têm condiçóes de proporcionar." Essa reconstruçáo exige o extrapolar do espaço definido pela câmera, requerendo uma análise mais profunda e subjetiva do leitor. "Após a identificação do conteúdo da fotografia é preciso deduzir o que não se vê, em torno daquilo que se está vendo" (Leite, 1993, p. 44). Vale destacar que, no decorrer das pesquisas, muito do que não se viu nas imagens foi identificado com o apoio das narrativas orais.

Os depoimentos dos sujeitos partícipes das açôes do Mobral encontram, no acervo fotográfico, apoio fundamental para realização do ato de rememorar. Nesse contexto, o aparecimento das fotografias, no momento das entrevistas, ajudou-me a perceber a necessidade da interaçáo entre essas duas fontes. Do mesmo modo, as fotografias adquirem novos sentidos a partir das narrativas que os sujeitos a elas atribuem quando as analisam. Os estudos de Mauad (2010, p. 145) são esclarecedores ao realçarem que "as fontes orais e visuais - fotográficas, [...] tomadas como fontes de memória, associam-se aos processos de rememoraçáo que criam narrativas sobre um determinado tempo e espaço passados." Esse entrelaçamento entre as fontes possibilitou, por meio da intuição e da leitura cuidadosa do texto e dos contextos presentes nas imagens, que se alcançassem interpretaçóes reconstrutivas de histórias, por intermédio da memória social de um grupo de sertanejos.

\section{Quarto itinerário: escavações em acervos documentais inexplorados}

No decorrer das pesquisas, tive a oportunidade de mobilizar a abordagem da História oral, tendo as entrevistas como fontes principais, porém não entendidas como fontes que se esgotam em si. Os relatos dos entrevistados passaram a compor uma rede 
documental, aliando-se a outras fontes - documentos escritos e imagens, encontrados a partir de um esforço feito no itinerário investigativo.

A composiçáo dessa rede documental exigiu a compreensão de que, ao trabalhar com a metodologia da História oral valorizam-se, também, outros documentos históricos, como no caso do tema em questáo. Segundo Alberti (2008, p.189): "o trabalho simultâneo com diferentes fontes e o conhecimento aprofundado do tema permite perceber 'dissonâncias' que podem indicar caminhos profícuos de análise das entrevistas de história oral". Isso aconteceu, no decorrer do percurso. A autora é enfática em destacar a importância da utilização de outras fontes, sobretudo para comparar as narrativas construídas a partir das entrevistas com outros documentos encontrados em arquivos.

A utilização da expressão acervos inexplorados, neste tópico, deve-se ao fato de que tive o privilégio de ser o primeiro pesquisador a explorar os documentos de um acervo que ainda estava em processo de organizaçáo no Centro de Referência e Memória da Educação Popular e Educação de Jovens e Adultos (Cremeja ${ }^{13}$ da UERJ, que conseguiu recuperar expressiva documentação, "quase toda ela soterrada pelos descaminhos do poder irresponsável que, ao extinguir instituiçóes públicas, despreza as construçóes realizadas, a despeito dos juízos de valor que a ela se dediquem" (Paiva, 2014, p. 7).

Esse momento ímpar não foi apenas de exploração, mas de vivenciar o trabalho de catalogaçáo do acervo documental que se constituiu como um centro de memória aberto a pesquisadores. No processo desta investigação, tive acesso a fontes documentais que não foram explorados durante a minha pesquisa de Mestrado (2011-2012) porque somente no Doutorado é que me foi proporcionado interagir no Programa de PósGraduação em Educação (ProPEd) da UERJ, por meio de um intercâmbio do Procad/ $\mathrm{CNPq}$, a que já me referi. Esse intercâmbio possibilitou o enriquecimento dos estudos, principalmente no que diz respeito ao contingente de informaçôes acerca do Mobral, que se configuraram como esclarecedoras de muitos depoimentos orais que já haviam sido coletados por meio das entrevistas.

Vale registrar que o acervo ao qual tive acesso possibilitou o estabelecimento de vinculaçóes entre o período em estudo, aclarando as concepçôes de educaçáo de adultos daqueles contextos bem como a intensidade das açóes do Mobral, por intermédio dos diversos programas implantados. As fontes documentais foram aquelas relacionadas ao meu objeto de estudo, entre as quais se destacaram: relatórios, monografias, artigos, números especiais sobre a temática e material didático - cartilhas, livros, folhetos e jornais. Essas fontes foram fundamentais para a compreensão de aspectos que não ficaram claros durante a realização das entrevistas e ajudaram, também, a perceber até que ponto algumas informaçóes dos relatos orais corroboravam ou não as informaçôes

13 No momento atual (2021), os documentos do Cremeja, de diferentes contextos históricos da Educação Popular e da EJA, podem ser acessados no acervo digital. Disponível em: http://cremeja.org/a7/paginainicial/cremeja/. Acesso em: 20 set. 2021. 
obtidas nas fontes documentais.

Outro acervo explorado que passou a enriquecer essa pesquisa foi a publicação de um E-book intitulado Educação Popular e Educação de Jovens e Adultos: memórias e histórias, organizado por Osmar Fávero ${ }^{14} \mathrm{e}$ Elisa Mota. ${ }^{15}$ Esse acervo, assim como o anteriormente citado, só passou a ser consultado durante o Doutorado, pois seu lançamento só ocorreu em dezembro de 2015. ${ }^{16}$ Trata-se de uma fonte de pesquisa singular que reúne um extenso banco de fontes documentais do campo da Educação Popular e da EJA no Brasil. O E-book comporta, em seus três DVD-Rom, o acervo que vinha sendo reunido ao longo dos últimos 60 anos, tendo como principal mentor o coordenador do Núcleo de Estudos e Documentação em Educação de Jovens e Adultos (Nedeja).

Muitos desses materiais são exemplares únicos, recolhidos em arquivos particulares, documentos salvos do pouco apreço à preservação de nossa memória ou que sobreviveram à desestruturação dos movimentos populares ocorrida no país após o golpe de 1964, guardados em situaçóes adversas: embaixo de caixas d'água, no teto de igrejas ou mesmo enterrados. (Fávero; Motta, 2015, p. 4).

Entre os três DVD-Rom que compóem o $E$-book, debrucei-me sobre um deles, intitulado Educação de Jovens e Adultos, no qual são apresentados, além de outras experiências, os programas federais dos anos de 1970 e 1980, do período dos governos autoritários.

Vale registrar que, no processo de incursão no campo de investigação, iniciado em 2011, alguns sujeitos entrevistados também abriram seus arquivos pessoais e, surpreendidos com o interesse do pesquisador em reconstruir a memória, doaram prontamente as valiosas fontes guardadas, entre as quais se destacam certificados de conclusão do PAF.

\section{Arremate provisório}

A História oral, as fotografias e os acervos documentais a que me referi neste texto foram utilizadas como fontes históricas que constituíram narrativas que demonstram, no itinerário metodológico das minhas pesquisas de Mestrado e Doutorado, como

14 Professor Emérito da Universidade Federal Fluminense (UFF), coordenador do Nedeja.

15 Mestranda em Educação, à época pela Pontifícia Universidade Católica do Rio de Janeiro (PUC-Rio), auxiliar de pesquisa no Nedeja.

16 Lançado no Seminário Documentação, Memória e História da Educação no Brasil, no dia 10 de dezembro de 2015, na Universidade Federal do Estado do Rio de Janeiro (Unirio). 
os sertanejos recriaram e reconstruíram sentidos em suas culturas, segundo suas possibilidades de atuaçáo no mundo, fazendo-se sujeitos a partir das experiências vividas. Permitiram, também, possíveis "respostas" às questôes levantadas nesses estudos, dando visibilidade à memória dos sertanejos que participaram das açôes PAF e do Mobral Cultural. Nesse sentido, as fontes recuperadas, além de me autorizarem a contar uma história que náo vivi, foram primordiais para o processo de reconstruçáa de parte da história de um Movimento que se configurou como uma campanha de base nacional, em um contexto autoritário.

Nessa direção, as fotografias utilizadas como fonte - com mensagens não verbais - permitiram a dinamicidade da memória dos sujeitos entrevistados e, também, a análise mais aguçada de minha parte enquanto pesquisador. Atrele-se a isso, também, o contato com a memória material de acervos documentais recuperados pelo Cremeja da UERJ e pelo Nedeja da UFF.

Essas memórias dos sujeitos esquecidos pela história oficial - testemunhas vivas trouxeram novas reflexôes sobre o Mobral, sobretudo em relação ao lugar - sertão - de onde brotaram narrativas diferentes das que povoam o imaginário nacional acerca do referido Movimento. Os estudos realizados tiveram sua relevância na necessidade de recriação das ações do Mobral nos sertōes alagoanos, a partir da tessitura de histórias e de memórias dos sertanejos; sobre como experienciaram e ressignificaram as açóes desenvolvidas pelo Mobral no contexto da Ditadura civil-militar. Tal ressignificação pode ser entendida como resultado de um conjunto de "maneiras de fazer" que, nas palavras de Certeau (2011, p. 41), "constituem as mil práticas pelas quais usuários se reapropriam do espaço organizado pelas técnicas de produção sociocultural”, ou seja, os sentidos atribuídos em suas próprias culturas às açóes apresentadas pelo PAF e Mobral Cultural na comunidade sertaneja.

Diante dessas oportunidades em um lugar carente, os sujeitos, na rememoração de suas experiências, expressaram uma forte aceitação do Mobral. As precárias condiçóes do campo educacional levaram os interlocutores a creditarem as açôes desenvolvidas pelo Mobral como positivas, fazendo com que explicitassem as benesses do Movimento, que supostamente "supria" o desprovimento deixado pelo Estado militar.

As falas foram sempre acompanhadas de saudosismo sobre as contribuiçóes advindas das açóes dos dois programas estudados e de outras implementadas pelo Movimento sem, no entanto, situarem-nas no contexto da Ditadura civil-militar, em plena vigência na época. As "respostas" construídas no decorrer dos estudos, originaramse, sobretudo, de um exercício de escuta e observação de fontes que, geralmente, não aparecem nos registros escritos oficiais, mas que são fontes que ajudaram na recriação da história do Mobral, a partir do recomendado por Walter Benjamin: "a contrapelo".

Nos sertóes de Alagoas, muitas reflexôes ainda permanecem em aberto configurando-se, portanto, como campo fértil de investigaçáo, devido à ausência de memória escrita. Esse despertar gera possibilidades de continuidade deste estudo e, 
também, para a continuidade via mobilização de outros pesquisadores interessados em reconstruir a história pelas lentes dos sujeitos ordinários esquecidos pela história oficial. Esses guardam, em suas lembranças, experiências significativas que merecem ser acionadas no momento presente, com o desígnio da valorização, da preservaçáo da memória, consequentemente, modificando visões monolíticas das histórias que, comumente, são contadas a respeito do Mobral.

$\mathrm{Na}$ dissertação e na tese, as fontes orais, fotográficas e os acervos documentais desconstruíram ideias prontas e (aparentemente) acabadas sobre determinados conhecimentos; revelaram a complexidade da pesquisa e da escuta de um pesquisador que se lançou a novas aventuras no complexo mundo científico. Essa imersão permitiu o ecoar de novas interpretaçóes que emergiram de memórias e de histórias de vida marcadas pela experiência - histórias muitas vezes não creditadas como possíveis.

Passadas mais de cinco décadas, essas composiçóes, sistematizadas neste artigo, podem dar pistas e realizar inflexóes nos desdobramentos dos centros de referência e de memória da EJA, que têm o compromisso de reconstruir um tempo pouco estudado da história da EJA no Brasil. Entendo que essa reconstruçáo implica a pesquisa em rede de colaboraçáo e parceria, a exemplo de iniciativas como o Procad/CNPq que, permitiu o intercâmbio entre grupos de pesquisa da Ufal e da UERJ. Salienta-se, finalmente, que essa experiência também precisa ser somada à de outras universidades do país, também interessadas na reconstrução da memória da EJA.

\section{Referências}

ALBERTI, Verena. Histórias dentro da história. In: PINSKY, Carla Bassanezi (Org.). Fontes históricas. São Paulo: Contexto, 2008. p. 155-202.

ALBUQUERQUE JR., Durval Muniz de. A invenção do Nordeste e outras artes. 5. ed. São Paulo Cortez 2011.

ALBUQUERQUE JR. Distante e/ou do instante: "sertôes contemporâneos", as antinomias de um enunciado. In: FREIRE, Alberto (Org.) Culturas dos sertôes. Salvador: EDUFBA, 2014.

AMADO, Janaína. O grande mentiroso: tradição, veracidade e imaginação em história oral. História, São Paulo, v. 14, p. 125-136, 1995.

ATLAS DO DESENVOLVIMENTO HUMANO NO BRASIL. Santana do Ipanema, AL. Rio de Janeiro: PNUD, IPEA, FJP, 2017. Disponível em: http://www.atlasbrasil.org.br/perfil/ municipio/270800. Acesso em: 4 mar. 2021.

BARROS, Luitgard de Oliveira Cavalcanti. Santana do Ipanema pelos caminhos da memória. In: MELO, José Marques de; GAIA, Rossana. (Org.) Sertão Glocal: um mar de ideias brota às margens do Ipanema. Maceió: Edufal, 2010. p. 65-78.

BENJAMIN, Walter. Magia e técnica, arte e politica: ensaios sobre literatura e história da escrita. 
8. ed. São Paulo: Brasiliense, 2012. (Obras Escolhidas, v. 1).

BOSI, Ecléa. Memória e sociedade: lembranças de velhos. 3. ed. São Paulo: Companhia das Letras, 1994.

CERTEAU, Michel. A invenção do cotidiano: 1 Artes de fazer. 17. ed. Petrópolis: Vozes, 2011.

CUNHA, Euclides da. Os sertóes. 30. ed. Rio de Janeiro: Francisco Alves, 1981.

DUARTE, Abelardo. Folclore negro das Alagoas: áreas da cana-de-açúcar: pesquisa e interpretação. 2. ed. Maceió: Edufal, 2010. (Coleção nordestina; v. 66).

FÁVERO, Osmar; MOTTA Elisa. (Org.). Educação de jovens e adultos. Petrópolis: DP et Alii; Rio de Janeiro: FAPERJ, 2015.

FERRARO, Alceu Ravanello. História inacabada do analfabetismo no Brasil. São Paulo: Cortez, 2009.

FREITAS, Marinaide Lima de Queiroz; MOURA, Tânia Maria de Melo. A Educação de Jovens e Adultos em Alagoas: incursóes na história das - açóes e concepçóes em âmbito governamental (1960-1980). In: GRACINDO, Regina Vinhaes et al. (Org.). Educação como exercício de diversidade: estudos em campos de desigualdades sócio educacionais. Brasília: Liber Livro, 2007. p. 129-149.

GERMANO. José Willington. Estado militar e educação no Brasil (1964-1985). 5. ed. São Paulo: Cortez, 2011.

LARROSA, Jorge. Tecnologias do eu e educação. In: SILVA, Tomaz Tadeu (Org.). O sujeito da educação. Petrópolis: Vozes, 2011. p. 35-86.

LEITE, Miriam Moreira. Retratos de família. São Paulo: Edusp, 1993.

MAUAD, Ana Maria. Através da imagem: fotografia e história interfaces. Tempo, Rio de Janeiro, v. 1, n. 2, p. 73-98, 1996.

MAUAD, Ana Maria. Fontes de memória e o conceito de escrita videográfica: a propósito da fatura do texto videográfico Milton Guran em três tempos (LABHOI, 2010). História oral, v. 13, n. 1, p. 141-151, jan./jun. 2010.

MOREIRA, Gislene. Mulher rendeira: re-tecendo afetos e identidades de gênero nos sertóes contemporâneos. Saculum, João Pessoa, v. 24, n. 41, p. 354-372, jul./dez. 2019.

PAIVA, Jane. Os sentidos do direito à educação para jovens e adultos. Petrópolis: Faperj: DP et Alii, 2009.

PAIVA, Jane. Projeto de memória em memória: trançando histórias na Educação de Jovens e Adultos. Rio de Janeiro: ProPEd/Uerj, 2014.

PAIVA, Vanilda. História da educação popular no Brasil: educação popular e educação de adultos. 6. ed. São Paulo: Ediçôes Loyola, 2003.

POLLAK, Michael. Memória, esquecimento, silêncio. Estudos Históricos, Rio de Janeiro, v. 2, n. 3, p. 3-15, 1989.

POLLAK, Michael. Memória e identidade social. Estudos Históricos, Rio de Janeiro, v. 5, n. 10, 
p. 200-2012, 1992.

PORTELLI, Alessandro. O que faz a história oral diferente. Projeto História, São Paulo, v. 14, 1997.

PORTELLI, Alessandro. Ensaios de história oral. São Paulo: Letra e Voz, 2010.

THOMPSON, Paul. A voz do passado: história oral. Rio de Janeiro: Paz e Terra, 1992.

\section{Fontes orais}

FARIAS, Alice Silva [72 anos]. [jan. 2012]. Entrevistador: Jailson Costa da Silva. Santana do Ipanema, AL, 28 jan. 2012.

FIALHO, Hélio Silva [57 anos]. [abr. 2015]. Entrevistador: Jailson Costa da Silva. Pão de Açúcar, AL, 6 abr. 2015.

MELO, Jeniuza Soares de [56 anos]. [jan. 2012]. Entrevistador: Jailson Costa da Silva. Santana do Ipanema, AL, 24 jan. 2012.

Recebido em 06/02/2021.

Versão final reapresentada em 04/06/2021.

Aprovado em 08/08/2021.

Certificado de Apresentaçáo de Apreciaçáo Ética (CAAE): 36363414.3.0000.5013.

Fonte de financiamento: Coordenação de Aperfeiçoamento de Pessoal de Nível (CAPES) - Bolsa.

Conflitos de interesse: nada a declarar. 